\title{
Naming and Necessity. Bigarren hitzaldia: 1970eko urtarrilaren 22a
}

\author{
Naming and Necessity. Lecture II: January 22, 1970 \\ SAUL KRIPKE \\ Harvard University Press. 1980, 71-105 or.
}

Ekain Garmendiak ingelesetik itzulia.

Azkenekoan, izendatzearen teoria bati buruz hitz egiten bukatu genuen; hemen, arbelean, dauzkagun tesi hauek ematen dute teoria hori:

(1) ' $X$ ' izen edo adierazpen designatzaile orori propietate sorta bat dagokio, alegia, $A \mathrm{k}$ ' $\phi X^{\prime}$ uste duen $\phi$ propietateen familia.

(2) Ak uste du propietateetako batek, edo batzuek batera, banako bakarra hautatzen dutela.

(3) $\phi$ horien gehiengoa, edo gehiengo kualifikatu bat, $y$ objektu bakar batek asetzen badu, orduan $y$ da ' $X$ 'ren erreferentea.

(4) Bozkak ez badu objektu bat eta bakarra ematen, ' $X$ 'k ez du erreferitzen.

(5) ' $X$ existitzen bada, orduan $X \mathrm{k} \phi$ gehienak dauzka' baiezpena a priori daki hiztunak.

(6) ' $X$ existitzen bada, orduan $X \mathrm{k} \phi$ gehienak dauzka' baiezpenak beharrezko egia bat adierazten du (hiztunaren idiolektoan).

(C) Edozein teoria arrakastatsurentzat, azalpenak ez du zirkularra izan behar. Bozkan erabiltzen diren propietateek eurek ez dute erreferentziaren nozioa erabili behar ezinezko izango bada azken batean hori kentzea. 
(C) ez da tesi bat, baizik eta beste tesiak asetzeko baldintza bat. Beste modu batera esanda, (1)-(6) tesiak ezin dira ase gurpil zoro bati bide emateko moduan, erreferentziaren mugapen independenteren bati bide ematen ez dion modu batean. Azkenekoan eman nuen adibide bat, baldintza horiek asetzeko saiakera ageriki zirkular batena: William Knealek aipatzen duen izenen teoria bat. Lehendik idatzita neukana irakurtzen ari nintzenean, harritu egin nintzen pixka bat teoriak zioenarekin eta, horregatik, berriro begiratu nuen. Liburuan begiratu nuen, ikusteko ea zuzen kopiatu nuen. Knealek erabiltzen zuen, bai, lehenaldia. Honela zioen: nahiz eta ez den hutsala inork zuri esatea Sokrates antzinako Greziako filosoforik handiena zela, bai da hutsala inork zuri esatea Sokratesi 'Sokrates' esaten ziotela. Horregatik, zera ondorioztatzen du: 'Sokrates' izenaren esanahiak izan beharko du, besterik gabe, "Sokrates" esaten dioten banakoa'. Russellek ere, esan nuen moduan, antzeko analisi bat ematen du non edo non. Nolanahi ere, lehenaldia erabiliz formulatuta, baldintza ez litzateke zirkularra izango, ziur erabaki baitzitekeen 'Sokrates' terminoa erabiltzea erreferentzia egiteko greziarrek 'Sokrates' esaten zioten dena delakoari. Baina, noski, zentzu horretan ez da inolaz ere hutsala inork zuri esatea Sokratesi 'Sokrates' esaten ziotela. Hori inolako gertakariren bat bada, faltsua izan liteke. Agian badakigu guk esaten diogula 'Sokrates'; horrek nekez erakusten du greziarrek ere hala egiten zutenik. Izan ere, agian izena desberdin ahoskatzen zuten, noski. Izan daiteke, izen jakin honen kasuan, grezierakoaren transliterazioa hain dela ona ezen ingelesezko* bertsioa ez dela grezierakoaren oso desberdin ahoskatzen. Baina, oro har, hori ez da horrela izango. Ziur, ez da hutsala inork zuri esatea Isaiasi 'Isaias' esaten ziotela. Izatez, faltsua da Isaiasi 'Isaias' esaten ziotela; profetak ez zukeen inolaz ere izen hori ezagutuko. Eta, noski, greziarrek ez zioten euren herrialdeari 'Grezia' gisako ezer esaten. Demagun tesia zuzentzen dugula, honako hau esateko: hutsala da inork zuri esatea Sokratesi 'Sokrates' esaten diogula guk edo, gutxienez, nik, hiztunak. Esan dezakegu zentzuren batean hori hutsala dela. Ez dut uste beharrezkoa edo analitikoa denik. Modu berean, hutsala da inork zuri esatea zaldiei 'zaldi' esaten diegula, eta honek ez garamatza ondorioztatzera 'zaldi' hitzak, besterik gabe, "'zaldi” esaten zaion animalia' esan nahi duela. 'Sokrates' izenaren erreferentziaren teoria gisara, gurpil zoro batera eramango gaitu zuzenean. Norbait bere buruarentzat 'Glunk' gisako izen baten erreferentea mugatzen ariko balitz, eta honako erabaki hau hartuko balu, "Glunk" terminoa erabiliko dut nik "Glunk" esaten diodan gizonari erreferentzia egiteko', horrek ez luke inora eramango. Hobe luke 'Glunk'en erreferentearen mugapen independenteren bat edukitzea. Mugapen zirkular ageri baten adibide ona da hori. Izan ere, 'Sokratesi "Sokrates" esaten diote' bezalako perpausak interesgarriak dira oso, eta, arraro irudi balezake ere, batek orduak eman ditzake horien analisiei buruz hizketan. Nik neuk egin nuen hori behin. Ez dut, nolanahi ere, horrela-

* Kripkek bere hitzaldiak ingelesez eman zituen, eta itzuli dudan jatorrizko testua ere ingelesez dago; horregatik, 'ingelesez' utzi dut hemen, nahiz eta testua euskaraz egon —itzultzailearen oharra-. 
korik egingo oraingo honetan. (Begira ba noraino irits daitezkeen hizkuntzaren urak. Baita sakonera txikieneko lekuetan ere). Edonola ere, zirkularitaterik ezaren baldintza hausten duen adibide aproposa da hori. Teoriak aseko ditu, agian, baiezpen horiek guztiak, baina asetzen ditu soilik badagoelako erreferentzia mugatzeko modu independenteren bat honako baldintza partikular honekiko independentea dena: 'Sokrates' esaten dioten gizona izatea.

Hitz egin dut jada, azken hitzaldian, (6) tesiari buruz. Bide batez, (5) eta (6) tesiek konbertsoak dauzkate. (5) tesiak dio, $X$ existitzen bada, $X \mathrm{k} \phi$ gehienak dauzkalako baiezpena a priori dela egiazkoa hiztunarentzat. Egia izango da, halaber, teoria horren pean, baiezpen horren konbertso jakin batzuk ere $a$ priori izango direla egiazkoak hiztunarentzat, alegia: gauzaren batek (eta berak bakarrik) $\phi$ propietateen gehiengo kualifikatu bat badauka, orduan $X$ da. Antzera, horren konbertso jakin bat derrigorrez izango da egiazkoa, alegia: ezerk $\phi$ propietateen gehiengo kualifikatu bat badauka, orduan $X$ da. Beraz, esan daiteke bai $a$ priori eta bai beharrezkoa dela zerbait $X$ dela baldin eta bakarrik baldin $\phi$ propietate gehienak dauzkan objektu bakarra bada. Hori aurreko (1)-(4) tesietatik dator, nik uste. Eta (5)ek eta (6)k, benetan, zera bakarrik diote: gogoeta nahikoa egiten duen hiztunak atzemango duela izen propioen teoria hori. Hori jakinda, ikusiko du, halaber, (5) eta (6) ere egiazkoak direla. (5) eta (6) tesien aurkako objekzioak ez dira izango hiztun batzuek ez daukatela teoria horren berri eta horregatik ez dakizkitela gauza horiek.

(6) tesiari buruz aritu nintzen azkeneko hitzaldian. Filosofo ugarik esan du izen propio batekin lotutako propietate sorta oso zentzu estuan hartzen bada, pisua propietate bakarrari emanez, demagun, deskripzio definitu bakarrak hautatuz erreferentea -adibidez, Aristoteles izan zen Alexandro Handiaren irakasle aritu zen filosofoa-, orduan beharrezko egiak ez diren gauza batzuk beharrezko egia suertatuko direla itxuraz — kasu honetan, adibidez, Aristoteles Alexandro Handiaren irakasle izan zela-. Baina, Searlek esan zuen moduan, Aristoteles irakaskuntzan aritu izana ez da egia beharrezkoa, baizik eta kontingentea. Horregatik ondorioztatzen du deskripzio bakarraren paradigma alde batera utzi beharko litzatekeela, eta deskripzio sortarena onartu.

Azkenekoan defendatu nituen gauza batzuk laburtzearren, hori ez da erantzun zuzena (hau edozein delarik ere) beharrezkotasunaren arazo horrentzat. Izan ere, Searlek honela jarraitzen du:

Demagun adosten dugula 'Aristoteles' alde batera utzi eta, adibidez, 'Alexandroren irakaslea' erabiliko dugula; orduan, egia beharrezkoa da erreferentzia egiten zaion gizona Alexandroren irakaslea dela —baina gertakari kontingentea da Aristoteles pedagogian aritu izana, nahiz eta iradokitzen ari naizen beharrezko gertakaria dela Aristotelesek egotzi ohi zaizkion propietateen batura logikoa, disjuntzio inklusiboa, daukala-... ${ }^{31}$

31 Searle, 'Proper Names', 160. orrialdea (Charles Edwin Caton (arg.): Philosophy and Ordinary Language, University of Illinois Press, Urbana, 1963). 
Horixe da hala ez dena. Ez da egia beharrezkoa, beharrezkotasunaren edozein zentzu intuitibotan, Aristotelesek egotzi ohi zaizkion propietateak zeuzkala. Badago teoria bat, hedatua dagoena agian historiaren filosofiako ikuskera batzuetan, determinista izanik ere aldi berean norbanakoari rol garrantzitsua aitortzen diona historian. Carlylek agian lotuko lituzke gizon handi baten lorpenak haren izenaren esanahiarekin. Halako ikuskera baten arabera, beharrezkoa izango da, jada norbanako jakin bat jaio denean, eginkizun handi ugari aurrera eramatera lotzea halabeharrak eta, beraz, Aristotelesen izaeraren beraren parte izango da Mendebaldean izugarrizko eragina izan zuten ideiak sortu beharko zituzkeela. Halako ikuskera batek historiari buruzko edo gizon handien izaerari buruzko ikuskera gisa izan ditzakeen merituak edozein izanik ere, ez dirudi tribialki egia izan beharko lukeenik izen propioei buruzko teoria baten oinarri hutsean. Balirudike gertakari kontingentea dela Aristotelesek hari gaur egun egotzi ohi zaizkion gauzetatik edozein, guk hainbeste miresten ditugun lorpen horietatik edozein, inoiz egin izana. Esan beharra daukat badagoela zerbait Searleren bihozkada horretan. 'Hitler' izena entzuten dudanean, sentitzen dut halako 'tripetako sentsazio' iruzurti bat esaten didana analitikoa-edo dela gizon hori gaiztoa zela. Baina, benetan, seguru asko ez. Hitlerrek pasa izan zezakeen bizi osoa Linzen, lasai askoan. Kasu horretan, ez genuke esango horregatik gizon hori ez zatekeenik Hitler izango, 'Hitler' izena gizon horren izen gisara erabiltzen baitugu hain justu, baita beste mundu posibleak deskribatzen ditugunean ere. (Hau da aurreko hitzaldian designatzaile zurrun esaten nion nozioa). Demagun bai erabakitzen dugula 'Hitler'en erreferentzia hautatzea historian beste inork baino judu gehiago hiltzea lortu zuen gizon gisa. Hori da izenaren erreferentzia hautatzeko daukagun modua; baina, sona txar hori irabazteko merituak beste norbaitek egingo zituzkeen egoera kontrafaktiko batean, ez genuke esango kasu horretan beste gizon hori izango zatekeela Hitler. Hitler ez balitz inoiz boterera iritsi izan, Hitlerrek ez zukeen propietate hori izango, emantzat jotzen ari naizena erabiltzen dugula bere izenaren erreferentzia zehazteko. Modu bertsuan, metro bat zer den metro-barra estandarraren erreferentzia erabiliz definitzen badugu ere, egia kontingentea izango da, eta ez beharrezkoa, barra partikular hori metro bat luze dela. Luzatu egin balitz, metro bat baino luzeago izango zatekeen. Eta hori hala da 'metro bat' terminoa luzera jakin bat zurrunki designatzeko erabiltzen dugulako. Nahiz eta luzera horri akzidentala zaion propietate baten bitartez zehaztu zein luzera ari garen designatzen, gizonaren izenaren kasuan gizona akzidentala zaion propietateren baten bitartez hauta dezakegun bezalaxe, izena erabiltzen dugu gizon hori edo luzera hori mundu posible guztietan designatzeko. Erabiltzen dugun propietateak ez du zertan izan beharrezkotzat edo esentzialtzat jotzen den bat. Yardaren kasuan, luzera hori hautatzeko erabili zen modua izan zen, uste dut, Ingalaterrako Henrike I.aren hatz-puntatik bere sudurrera zegoen distantzia besoa zabaltzen zuenean. Hori bazen yarda baten luzera, horregatik ez litzateke egia beharrezkoa izango Henrike I.aren hatz-puntatik 
sudurrerako distantziak yarda batekoa izan beharko zuenik. Agian, besoa txikiagotuko zion istripu bat gerta zitekeen; posible da. Eta beharrezko egia ez izateko arrazoia ez da egon litezkeela beste irizpide batzuk yarda bat izatearen 'sorta-kontzeptuan'. Henrike Erregearen besoa bere luzera estandar gisara zorrotz erabiltzen duen gizon batek ere esan dezake, kontrafaktikoki, gauza batzuk gertatu izan balitzaizkio Erregeari, bere hatz-puntaren eta sudurraren arteko distantzia zehatza ez zatekeela zehazki yarda bat izango. Ez du zertan propietate sorta bat erabili, 'yarda' terminoa erabiltzen ari den heinean erreferentzia jakin bat hautatzeko eta berau luzera hori izateko mundu posible orotan.

Ohar horiek erakusten dute, nik uste, 'munduz munduko identifikazioa'ri eta 'kontraparteen teoria'ri buruz idatzita dagoenaren zati handi bat intuitiboki arraroa dela. Tankera horretako teoriko askok baitiote, 'mundu posible' bat kualitatiboki bakarrik aurkezten zaigula uste dutenez, Aristoteles 'beste mundu posibleetan identifikatu' egin behar dela, edo, bestela, bere kontraparteak identifikatu behar direla, bere propietate garrantzitsuenetan Aristotelesen antza handiena duten beste mundu posibleetako gauza horiekin. (Lewisek, adibidez, honela dio: 'Zure kontraparteek ... zure antza daukate ... alderdi garrantzitsuei dagokienez ... beren munduan dauden beste gauzek baino gehiago ... alderdi bakoitzaren garrantziak eta antzekotasun graduek kualifikatuta.' ${ }^{\prime 2}$ ) Zenbaitek berdindu egin ditzakete ezaugarri garrantzitsuak eta mundu errealean objektua identifikatzeko erabilitako propietateak.

Nozio horiek okerrak dira, ziur. Niretzat, Aristotelesen propietate garrantzitsuenak bere obra filosofikoan dautza, eta Hitlerrenak bere rol politiko kriminalean; bazitekeen, esan dudan moduan, biek ala biek propietate horietatik batere eduki ez izana. Kontu ziurra da ez zegoela Aristotelesen eta Hitlerren pausoak gidatzen zituen patu logikorik, saihetsezina egiten zuena haien kasuan garrantzitsutzat jotzen ditugun propietate horiek edukitzea; izan ahal zituzten ibilbide zeharo desberdinak benetan izan zituztenen aldean. Objektu baten propietate garrantzitsuek ez dute zertan esentzialak izan, 'garrantzia' ez bada esentziaren sinonimotzat erabiltzen, behintzat; eta objektu batek izan ahal zituen benetan dauzkan eta deigarrienak zaizkion propietateetatik oso desberdinak zitezkeen propietateak, edo berori identifikatzeko erabiltzen ditugun propietateetatik oso desberdinak liratekeenak.

Askok galdetu didaten gauza bat argitzearren: designatzaile bat zurruna dela eta mundu posible orotan gauza bera designatzen duela diodanean, esan nahi dudana da, gure hizkuntzan erabiltzen den gisan, gauza horren ordez dagoela, guk egoera kontrafaktikoei buruz hitz egiten dugunean. Ez dut

32 D. Lewis: 'Counterpart Theory and Quantified Modal Logic', Journal of Philosophy 65, 1968, 114-15 
esan nahi, noski, ezin egon litezkeenik egoera kontrafaktikoak, zeinetan beste mundu posibleetan jendeak hizkuntza desberdin bat hitz egiten zuen. Ez diogu 'bi gehi bi lau da' kontingentea dela, zergatik eta egon zitekeelako 'bi gehi bi lau da' baiezpenak zazpi bikoitia dela esan nahiko zukeen hizkuntza bat. Antzera, egoera kontrafaktiko bati buruz hitz egiten dugunean, ingelesez hitz egiten dugu hari buruz, nahiz eta egoera kontrafaktiko horren deskripzioaren parte izan daitekeen egoera kontrafaktiko horretan gu denok alemanez ari garela hitz egiten. Esaten dugu 'demagun denok alemanez ari ginela' edo 'demagun ingelesa modu ez-estandar batean erabiltzen ari ginela'. Horrela, deskribatzen ariko gara mundu posible edo egoera kontrafaktiko bat zeinean jendeak, tartean guk, hitz egiten dugun moduaz bestela hitz egingo zukeen. Baina, halere, mundu hori deskribatzean, ingelesa erabiltzen dugu gure esanahiekin eta gure erreferentziekin. Zentzu horretan esan nahi dut designatzaile zurrunek erreferentzia bera daukatela mundu posible orotan. Ez dut inplikatu nahi, ezta ere, designatutako gauza mundu posible orotan existitzen denik; izenak gauza hori zurrunki erreferitzen duela, besterik ez. Esaten baduzu 'demagun Hitler ez zela inoiz jaio', orduan, 'Hitler'ek hemen erreferitzen du, zurrunki, deskribatutako egoera kontrafaktikoan existituko ez litzatekeen zerbait.

Ohar horiek onartuta, (6) tesia okertzat jo behar dugu. Beste tesiek ez daukate zerikusirik beharrezkotasunarekin, eta euts diezaiekegu. Zehazki, (5) tesiak ez dauka zerikusirik beharrezkotasunarekin, eta manten dezakegu. 'Hesperus' izena erabiltzen badut arratsean zeru-posizio jakin batean ikus daitekeen planeta-gorputz bati erreferentzia egiteko, ez da horregatik beharrezko egia izango Hesperus inoiz arratsean ikusiko dela. Hori gertakari kontingente ugariren araberakoa izango da; han hura ikusteko jenderik badagoen, eta horrelakoen araberakoa. Beraz, nahiz eta nik erabaki 'Hesperus' erabiliko dudala izendatzeko arratsean zeruan posizio horretan ikusten dudan gorputz zerutar hori, ez da beharrezkoa izango Hesperus inoiz arratsean ikusi izan denik. Baina izan daiteke a priori, erreferentzia horrela mugatu dudan heinean. Zehaztu badut Hesperus dela arratsean hor zehar ikusi nuen gauza, orduan, jakingo dut, erreferentearen mugapen hori egite hutsagatik, batere Hesperusik badago, arratsean ikusi nuen gauza dela. Orain arte eman ditugun argudioak bakarrik izanda kontuan, horrek behintzat badirau, oraingoz.

Zer esan (6) tesia baztertzen duen teoria bati buruz? (2), (3) eta (4) tesiek kontradibide pilo bat daukate. (2)-(4) tesiak egiazkoak direnean ere, (5) tesia faltsua izan ohi da; (3) eta (4) tesien egia 'akzidente' enpiriko bat da, hiztunak nekez ezagutzen duena a priori. Alegia, egiazki beste printzipio batzuek mugatzen dute hiztunaren erreferentzia, eta erreferentea (2)-(4) tesiek mugatzen duten horrekin bat etortzea 'akzidentea' da, a priori jakiteko moduan ez geundena. Kasu bakanetan bakarrik dira (2)-(5) denak egiazkoak; normalean, hasierako bataioetan. 
Izendatzearen zer irudi ematen dute (1)-(5) tesi horiek? Honako hau da irudia. Objektu bat izendatu nahi dut. Hura (eta hura bakarrik) deskribatzeko moduren bat pentsatzen dut eta, gero, nolabait esatearren, halako zeremonia mentala eramaten dut aurrera: 'Zizeron'en bitartez Katilina salatu zuen gizona esan nahiko dut; eta hori izango da 'Zizeron'en erreferentzia. 'Zizeron' erabiliko dut Katilina salatu zuen gizona zurrunki designatzeko, eta, horrela, hala egin ez zuen mundu posibleei buruz ere hitz egin ahal izateko. Baina, halere, nire asmoak ematen dira aurrena, objektu bakarra mugatzen duen baldintzaren bat emanez, eta, gero, hitz jakin bat erabiliz baldintza horrek mugatzen duen objektuaren izen gisara. Bada, egon daitezke egiaz horrela jokatzen dugun kasu batzuk. Agian, pixka bat behartuz deskripzio esan nahi badiozue, norbaitek esaten duenean: horko gorputz zerutarrari 'Hesperus' esango diot. ${ }^{33}$ Hori bai da kasu bat non, egiazkoak izateaz gain, tesiek ematen duten ere irudi bat, erreferentzia nola mugatu den zuzen deskribatzen duena. Beste kasu bat, honi izen esan nahi badiozue, izan liteke Londresko poliziak 'Jack' edo 'Jack tripa-ateratzailea' izena erabiltzen duenean hilketa horiek denak, edo gehienak, egin zituen gizonari erreferentzia egiteko, hura edozein delarik ere. Horrela, izenaren erreferentzia deskripzio baten bitartez ari dira ematen. ${ }^{34}$ Baina kasu askotan, edo gehienetan, tesiak faltsuak direla uste dut. Eman diezaiegun begiratu bat, bada. ${ }^{35}$

33 Badago kasu hobe bat, izen baten erreferentzia ostentsio bidez ez eta deskripzio bidez mugatzearena: Neptuno planetaren aurkikuntza. Neptuno hipotesi moduan proposatu zen, beste planeta batzuen orbitetan honelako-eta-horrelako desegokitzeak sortzen zituen planeta gisa. Benetan Leverrierrek planetari 'Neptuno' izena eman bazion inork hura inoiz ikusi baino lehenago, orduan 'Neptuno'ren erreferentzia oraintxe aipatutako deskripzioaren bitartez zehaztu zuen. Garai hartan ezin zuen planeta are teleskopioaren bitartez ere ikusi. Fase horretan, a priori baliokidetza materiala zegoen 'Neptuno existitzen da' eta 'honako eta halako planeten orbitetan perturbazioak eragiten dituen planetaren bat existitzen da honako eta halako posizioan' baiezpenen artean; eta, halaber, 'honako eta halako perturbazioak planeta batek eragiten baditu, Neptunok eragiten ditu' bezalako baiezpenek a priori egien estatusa zuten. Edonola ere, ez ziren beharrezko egiak, 'Neptuno' planeta zehatz bat zurrunki designatzen duen izen moduan sartu baitzen. Leverrierrek uste izan zezakeen, milioi bat urte lehenago Neptuno bere bidetik desbideratu izan balitz, orduan ez zukeela halako perturbaziorik eragingo, eta baita beste objekturen batek kausa izan zitzakeela perturbazioak haren ordez ere.

34 Donnellanek deskripzio definituei buruz egiten dituen oharrei jarraiki, gehitu beharko genuke kasu batzuetan identifika daitekeela objektu bat, eta izen baten erreferentzia zehaztu, objektuaz faltsu gerta daitekeen deskripzio bat erabiliz. Adibide argia da 'Phosphorus'en erreferentzia 'goizeko izarra' deskripzioaren bitartez mugatzea, gero gertatzen baita Phosphorus ez dela izar bat. Halako kasuetan, argi dago ez dela inongo zentzutan a priori ezagutzen erreferentzia zehazten duen deskripzioa objektuari buruz egiazkoa dela, nahiz eta kontu handiagoarekin hartutako ordezkoren bat agian bai ezagut daitekeen horrela. Horrelako ordezkorik eskura badago, ordezkoa da benetan erreferentzia zehazten duena, testuan eman nahi zaion zentzuan.

35 Tesietako batzuk nahiko baldar daude emanda, komatxoen erabilerari eta gisa horretako auzi lausoei dagokienez. (Adibidez, (5) eta (6) tesiek, adierazi diren moduan, aurresuposatzen dute hiztunaren hizkuntza ingelesa dela.) Tesien jomuga argi dagoenez, eta nolanahi ere faltsuak direnez, ez dut horrelakoak zuzentzeko lanik hartu. 
(1) tesia, esan dudan moduan, definizio bat da. (2) tesiak dio Ak uste duela objektuaz uste dituen propietateetako batek, edo horietako batzuek batera, indibiduoren bat eta bakarra hautatzen dutela. Jendeak buruan izan ohi duen adibide antzeko bat da, hain justu, esan dudana: 'Zizeron' izena erabiliko dut Katilina salatu zuen gizona denotatzeko (edo, hori bakarra izan dadin, Katilina publikoki salatzen lehena izan zen gizona denotatzeko). Horrek objektu bakar bat hautatzen du erreferentzia partikular honetan. Izenek inongo zentzutan esanahirik badaukatenik ukatzen duten autore batzuek ere, adibidez Ziffek Semantic Analysisen, uste dute erreferentzia mugatzeko moduaren irudi ona dela hori.

Ikus dezagun ea (2) tesia egiazkoa den. Badirudi, a priori moduren batean, egiazkoa izan behar duela; izan ere, ez baduzu uste buruan dauzkazun propietateek gauza bakarra hautatzen dutela - demagun bi pertsonak asetzen dituztela horiek denak-, orduan nola esan dezakezu bi horietatik zeini buruz ari zaren hizketan? Badirudi ez dagoela oinarririk esateko batari buruz ari zarela, eta ez besteari buruz. Normalean, emantzat jotzen da halako propietateak dena delako pertsonaren ekintza ezagun batzuk direla. Adibidez, Zizeron Katilina salatu zuen gizona zen. Horren arabera, Zizeroni erreferentzia egiten dionean, pertsona arrunta 'Katilina salatu zuen gizona'ren moduko zerbait ari da esaten eta, horrela, gizon bakar bat hautatu du. Filosofoek tesi hau hainbeste denboran onartu izana beraien kulturaren erakusgarri da. Izatez, jende gehienak, Zizeroni buruz pentsatzen duenean, hiztun erromatar ezagun bati buruz pentsatzen du, hiztun erromatar ezagun bakarra dagoela pentsatzeko asmorik gabe, edo izenarentzat erreferente bat izateko Zizeroni buruz zerbait gehiago jakin behar dela pentsatzeko asmorik gabe. Hartu adibide gisa Richard Feynman; gutako askok egin diezaiokegu hari erreferentzia. Fisikari teoriko garaikide ezaguna da. Hemen bildutako edonor da (ziur nago!) Feynmanen teorietako baten edukiak azaltzeko gai, horrela hura eta Gell-Mann desberdinduz. Edonola ere, kaleko gizonak, gaitasun horiek ez izanagatik, erabil dezake, nolanahi ere, 'Feynman' izena. Galdetzen bazaio, erantzungo du: tira, fisikaria-edo da. Ez du zertan pentsatu horrek pertsona bakarra hautatzen duenik. Eta, halere, uste dut 'Feynman' izena Feynmanentzako izentzat erabiltzen duela.

Baina bota diezaiegun begiratua pertsona bakar bat hautatzen duen deskripzio bat badaukagun kasu batzuei. Demagun, adibidez, badakigula Zizeron izan zela Katilina lehenik salatu zuen gizona. Tira, ondo dago hori. Horrek bai hautatzen du benetan pertsona bakar bat. Edonola ere, arazo bat dago, deskripzio honek beste izen bat ere biltzen baitu; 'Katilina', alegia. Ziur egon behar dugu zirkularitaterik ezaren baldintza urratzea saihesteko moduan asetzen ditugula baldintzak hemen. Zehatzago, ezin dugu esan Katilina dela Zizeronek salatu zuen gizona. Hori egiten badugu, benetan ez gara gauza bat eta bakarra hautatzen ariko; $A$ eta $B$ objektu parea hautatzen ariko gara, ezen $A \mathrm{k} B$ salatu baitzuen. Ez dugu uste hori denik halako salaketak 
inoiz gertatu zitzaizkion pare bakarra; beraz, hobe genuke beste baldintza batzuk gehitzea, bakartasun-baldintza asetze aldera.

Esaten badugu Einstein izan zela erlatibitatearen teoria aurkitu zuen gizona, horrek, ziur, hautatzen du pertsona bakar bat. Ziur egon gaitezke, esan dudan moduan, hemen dagoen edonork eman dezakeela teoria horren adierazpen trinko eta independente bat, eta, horrela, Einstein (eta Einstein bakarrik) hautatu; baina jende askok benetan ez daki nahikoa gai hauei buruz eta, beraz, erlatibitatearen teoria zer den galdetzen zaienean, esango dute: 'Einsteinen teoria', eta, horrela, litekeen gurpil zororik sinpleenean eroriko dira.

Beraz, sinpleki, (2) tesia ez da asetzen esaten dugunean Feynman fisikari famatua dela, Feynmani beste ezer egotzi gabe. Tesi hori, halaber, ez da egoki asetzen beste modu batera asetzen denean ere: esaten badugu Einstein zela 'erlatibitatearen teoria aurkitu zuen gizona', horrek hautatzen du pertsona bakar bat; baina gerta daiteke ez hautatzea zirkularitaterik ezaren baldintza asetzeko moduan, erlatibitatearen teoria bere aldetik hauta baitaiteke 'Einsteinen teoria' gisan. Beraz, (2) tesia faltsua dela dirudi.

Filosofoek izenekin lotu ohi dituzten $\phi$ baldintzak aldatuz, bat saia daiteke teoria hobetzen. Hori egiteko modu ugari entzun dut; agian, eztabaidatuko ditut horiek geroago. Normalean, izendatutako gizonak egindako lorpen famatuei buruz pentsatzen dute. Gauza ziurra da lorpen famatuen kasuan teoriak ez duela funtzionatzen. Nire ikasle batek behin esan zidan 'Tira, Einsteinek erlatibitatearen teoria aurkitu zuen'; eta 'erlatibitatearen teoria'ren erreferentzia independenteki mugatu zuen teoriaren xehetasunak emango zituen entziklopedia bati erreferentzia eginez. (Horri esaten zaio entziklopedien existentziaren dedukzio transzendentala). Baina, iruditzen zait, norbaiti entziklopediak ezagun zaizkion kasuan ere, bere erreferentziarako ez dela esentziala jakin beharko lukeela teoria hori zehatz-mehatz azaltzen dela inongo entziklopediatan. Erreferentziak ondo funtziona lezake, baita inoiz batere entziklopediarik izan ez balitz ere.

Segi dezagun (3) tesiarekin: $\phi$ propietateen gehiengo kualifikatu bat $y$ objektu bakar batek asetzen badu, orduan $y$ da izenaren erreferentea hiztunarentzat. Orain, jada finkatu dugunez (2) tesia okerra dela, zergatik funtzionatuko luke gainerakotik ezerk? Teoria osoa honako honen mende zegoen: beti zehaztu ahal izatea asetzen diren baldintza esklusiboak. Baina beste tesiei begira diezaiekegu oraindik. Teoriari lotzen zaion irudia da propietate esklusibo batzuk emanda bakarrik jakin dezakezula norbait zein den, eta horrela jakin zein den zure izenaren erreferentzia. Tira, ez naiz sartuko norbait zein den jakitearen auzian. Benetan da korapilatsua. Uste dut badakizula nor den Zizeron, erantzun badezakezu hiztun erromatar famatu bat dela. Arraro izan arren, baldin badakizu Einsteinek erlatibitatearen teoria aurkitu zuela eta ez badakizu ezer teoriari buruz, ezagutza horren oinarrian jakin dezakezu bai nor zen Einstein, alegia, erlatibitatearen teoria aurkitu zuena, eta bai nork 
aurkitu zuen erlatibitatearen teoria, alegia, Einsteinek. Badirudi hori nolabaiteko zirkularitaterik ezaren baldintzaren baten urratze argia dela; baina horrela mintzatzen gara. Balirudike, beraz, baldintza horren alde egiten duen irudi batek irudi okerra izan beharko duela.

Demagun $\phi$ gehienak asetzen dituela objektu bakar batek. Derrigorrez al da objektu hori ' $X$ 'ren erreferentea Arentzat? Demagun norbaitek esaten duela Gödel dela aritmetikaren osotasunik eza frogatu zuen gizona, eta gizon horrek badakiela nahikoa, eta gai ere badela osotasunik ezaren teoremaren azalpen independente bat emateko. Ez du besterik gabe esaten: 'Tira, hori Gödelen teorema da', edo horrelakorik. Teorema jakin bat ematen du, eta Gödeli egozten dio horren aurkikuntza. Betetzen al da, beraz, $\phi$ gehienak $y$ objektu bakar batek asetzen baditu, orduan $y$ dela ' $X$ ' izenaren erreferentea Arentzat? Har dezagun kasu sinple bat. Gödelen kasuan hori da berari buruz jende askok entzun duen ia gauza bakarra — aritmetikaren osotasunik eza aurkitu zuela-. Ondorioztatzen al da aritmetikaren osotasunik eza aurkitu zuen edonor 'Gödel'en erreferentea izango dela?

Imajinatu guztiz fikziozkoa den honako egoera hau. (Espero dut Gödel irakaslea ez dela hemen egongo). Demagun Gödel ez dela benetan teorema honen egilea. 'Schmidt' izeneko gizon bat, zeinen gorputza baldintza misteriotsuetan aurkitu zuten Vienan duela urte asko, izan zen benetan lan hori egin zuena. Bere lagun Gödel eskuizkribuaren jabe egin zen nolabait eta, horren ondorioz, Gödeli aitortu zitzaion. Kontuan hartzen ari garen ikuspegiaren arabera, beraz, gizon arruntak 'Gödel' izena erabiltzen duenean, benetan Schmidti erreferentzia egiteko asmoa dauka, Schmidt baita 'aritmetikaren osotasunik eza aurkitu zuen gizona' deskripzioa asetzen duen pertsona bakarra. Noski, saia zintezke deskripzioa honela aldatzen: 'aritmetikaren osotasunik ezaren aurkikuntza argitaratu zuen gizona'. Istorioa pixka bat aldatuz formulazio hori ere faltsu bihur daiteke. Edonola ere, baliteke jende gehienak ez jakitea ere froga argitaratu egin ote zen edota ahoz aho zabaldu ote zen. Gera gaitezen 'aritmetikaren osotasunik eza frogatu zuen gizona' horrekin. Beraz, aritmetikaren osotasunik eza frogatu zuen gizona benetan Schmidt denez, 'Gödel'i buruz hitz egiten dugunean, benetan Schmidti egiten diogu erreferentzia beti. Baina ezetz iruditzen zait niri. Ez dugu hala egiten. Erantzun bat, aurrerago eztabaidatuko dudana, honako hau izan liteke: horren ordez esan beharko zenuke 'aritmetikaren osotasunik eza egotzi ohi zaion gizona', edo horrelako zerbait. Aurrerago ikusiko dugu zer egin dezakegun horrekin.

Baina, agian, zuetako askori irudituko zaio adibidea oso arraroa dela, edota halako egoerak oso gutxitan gertatzen direla. Hori ere bada filosofoen kulturaren erakusgarri. Askotan erabiltzen dugu izen bat informazio okerrean oinarrituta. Fikziozko adibidean erabilitako matematikaren kasua adibide ona da. Zer dakigu Peanori buruz? Gela honetan dagoen jende askok Peanori buruz 'jakin' dezakeena da zenbaki arrunten segida ezaugarritzen duten axioma 
jakin batzuk, 'Peano axiomak' esan ohi zaienak, aurkitu zituena dela. Seguru asko, horiek zerrendatu ere egin ditzakete batzuek. Esan didate axioma horiek aurkitzen lehena ez zela Peano izan, baizik eta Dedekind. Noski, Peano ez zen iruzurti bat. Esan didatenez, bere oin-oharretan egin zion aitortza Dedekindi. Nolabait, ez zaio oin-oharrari kasurik egin. Beraz, kontuan hartzen ari garen teorian 'Peano' terminoak, erabiltzen dugun moduan, benetan Dedekind erreferitzen du -hori entzun duzuelarik, ikusten duzue denbora guztian benetan Dedekindi buruz ari zinetela hizketan-. Baina ez zineten horrela ari. Horrelako adibideak mugarik gabe biderka daitezke.

Gaizki-ulertu are okerragoak egiten ditu kaleko gizonak, noski. Aurreko adibide batean suposatzen nuen jendeak Einstein identifikatzen zuela erlatibitatearen inguruan egindako bere lanari erreferentzia eginez. Bada sarri entzun izan dut Einsteinen lorpen famatuena bonba atomikoaren asmakuntza dela. Beraz, Einsteini erreferentzia egiten diogunean, bonba atomikoaren asmatzaileari egiten diogu erreferentzia. Baina hori ez da horrela. Kolon izan zen Lurra biribila dela ohartzen lehen gizona. Bera izan zen, halaber, Mendebaldeko hemisferioa zapaltzen lehen europarra. Seguru asko, gauza hauetatik bat bera ere ez da egia, eta, beraz, jendeak 'Kolon' terminoa erabiltzen duenean, benetan, greziar bati egiten dio erreferentzia, Lurraren biribiltasuna erabiltzen badu, edota bikingoren bati, agian, 'Amerikaren aurkikuntza' erabiltzen badu. Baina ez da hori horrela. Beraz, ez dirudi $\phi$ gehienak $y$ objektu bakar batek asetzen baditu, orduan $y$ denik izenaren erreferentea. Badirudi hori faltsua dela. ${ }^{36}$

${ }^{36}$ Izendatzearen deskripzio sortaren teoriari jarraiki, 'Peanok zenbakien teoriaren axiomak aurkitu zituen'ek egia tribial bat adieraziko luke, ez gaizki-ulertu bat; eta berdin litzateke zientziaren historian gertatu diren beste gaizki-ulertu batzuentzat. Halako kasuak onartu dizkidaten batzuek zera proposatu didate: badaudela izen propio beraren beste erabilera batzuk sorta-teoria asetzen dutenak. Adibidez, proposatzen dute, esaten badugu 'Gödelek aritmetikaren osotasunik eza frogatu zuen', noski, Gödeli ari garela erreferentzia egiten, ez Schmidti. Baina, esaten badugu 'Gödelek argudio diagonal bat erabiltzen du frogaren pauso honetan', ez al diogu hemen, agian, teorema frogatu zuen edonor horri egiten erreferentzia? Modu bertsuan, norbaitek galdetzen badu 'Zer zeukan Aristotelesek (edo Shakespearek) buruan hemen?', ez al da hitz egiten ari pasarte horren autoreari buruz, hori edonor izanik ere? Donnellanen deskripzioen erabileraren analogiaz, horri izen propioen erabilera 'atributiboa' esan lekioke. Hori horrela bada, orduan, Gödel-Schmidt istorioa onartuta, 'Gödelek osotasunik ezaren teorema frogatu zuen' perpausa faltsua da, baina 'Gödelek argudio diagonala erabiltzen du frogan' (testuinguru batzuetan behintzat), egiazkoa, eta 'Gödel' izenaren erreferentzia anbiguoa da. Oraindik kontradibide batzuk badirenez, deskripzio sortaren teoria, oraindik, oro har, faltsua izango litzateke, eta horixe zen nire xede nagusia testuan; baina nik uste baino kasu mota gehiagotan izango litzateke aplikagarria. Nolanahi ere, uste dut ez dela zertan halako anbiguotasunik postulatu. Agian egia da, batzuetan, norbaitek 'Gödel' izena erabiltzen duenean, bereziki interesatzen zaiona teorema frogatu zuen edonor hori dela eta, agian, zentzuren batean, egiten diola 'erreferentzia'. Ez dut uste kasu hau 25. orriko 3. oin-oharreko Smith eta Jonesen kasuaren aldean desberdina denik. [Itzultzailearen oharra. Lehenengo hitzaldian eztabaidatzen duen adibide bati buruz ari da Kripke hemen. Adibidean bi lagunek hirugarren bat ikusten dute urrutira, eta 'Zertan ari da Jones? galdetzen du bietako batek. 'Orbelak jasotzen', erantzuten dio besteak. Ikusten duten pertsona ez da Jones, Smith baizik, baina, Krip- 
(4) tesia: bozkak ez badu objektu bat eta bakarra ematen, izenak ez du erreferitzen. Egia esan, kasu honi egin diogu kontu lehenago —nire aurreko adibideek egin diote kontu-. Aurrena, bozkak ez du zertan objektu bakarra eman, Zizeronen edo Feynmanen kasuan bezala. Bigarrenik, demagun bozkak ez duela batere objekturik ematen; ezerk ez dituela $\phi$ gehienak, edo horien kopuru dezenteko bat, asetzen. Esan nahi al du horrek izenak ez duela erreferitzen? Ez: pertsona bati buruz dauzkazun uste faltsuak beste bati buruz egiazkoak izan daitezkeen modu berean, izan ditzakezu uste faltsuak inori buruz egiazkoak ez direnak. Eta horiek izan daitezke zure uste guztiak. Demagun, Gödelen adibidea pixka bat aldatzeko, ez zuela inork aurkitu aritmetikaren osotasunik eza —agian, atomo batzuk zori hutsez pilatu ziren eta, besterik gabe, paper batean egikaritu zen froga-; Gödelek zortea izan zuen, aurrean baitzegoen gertakari bitxi hura gertatu zenean. Are gehiago: demagun aritmetika, benetan, osoa dela. Ez da espero izatekoa atomo batzuen zori hutsezko pilaketa batek froga zuzen bat sortuko duenik. Badago akats sotil bat, hamarkadetan oharkabean pasatu dena, oraindik inork ikusi ez duena —edo, agian, ez da benetan oharkabean pasatu, baina Gödelen lagunak...-. Beraz, baldintzak objektu bakar batek asetzen ez dituenean ere, izenak, halere, erreferitu dezake. Jonasen kasua eman nizuen lehengo astean. Biblian adituek, esan nizuen moduan, uste dute Jonas benetan existitu zela. Eta ez pentsatzen dutelako bazela norbait noizbait arrain handi batek irentsi zuena, edota Ninivera predikatzera joan zena. Agian baldintza horiek ez dira egiazkoak inori buruz, eta, halere, 'Jonas' izenak erreferente bat dauka benetan. Einsteinek bonba asmatu zuelako goiko adibidean, seguru asko inork ez du merezi bonbaren 'asmatzailea' dei diezaioten.

(5) tesiak dio ' $X$ existitzen bada, orduan $X \mathrm{k} \phi$ gehienak dauzka' baiezpena a priori dela egia Arentzat. Nabarmendu dezagun, (3) eta (4) egiazko gertatzen diren kasu batean ere, nekez dakiela hiztun arrunt batek $a$ priori horiek egiazkoak direla, teoriak eskatzen duen moduan. Gödeli buruzko nire ustea benetan egia dela uste dut eta 'Schmidt'en istorioa fantasia hutsa dela. Baina usteak nekez osatzen du a priori ezagutzarik.

kek dioenez, bi lagunek lortzen dute nolabait Smithi erreferentzia egin eta orbelak jasotzen ari dela esatea. Gainera, okertu eta lehenengo hitzaldiko adibidean erabili zituen izenak aldrebes erabiltzen ditu hemen Kripkek] Jones Smithekin nahasten badut, agian egiten diot erreferentzia (zentzu egoki batean) Jonesi, Smith orbelak jasotzen ari dela diodanean; edonola ere, ez dut 'Smith' anbiguoki erabiltzen, batzuetan Smithen eta besteetan Jonesen izen moduan, baizik eta unibokoki Smithen izentzat. Modu bertsuan, oker uste badut Aristotelesek halako-eta-halako pasartea idatzi zuela, agian erabiltzen dut batzuetan 'Aristoteles' pasarteak benetan idatzi zituenari erreferentzia egiteko, nahiz eta ez dagoen anbiguotasunik izenaren nire erabileran. Bi kasuetan, nire hasierako baiezpena eta izenaren nire hasierako erabilera atzera botako ditut, gauzak nola diren aurkitzen badut. Gogoan izan, hitzaldi hauetan, 'erreferente' zentzu teknikoan erabiltzen dudala, izen batek izendatzen duen gauzarentzat (edo deskripzio bat asetzen bakarra den gauzarentzat), eta ez luke nahasmenik egon behar. 
Zer ari da gertatzen hemen? Salba al dezakegu teoria? ${ }^{37}$ Aurrena, norbait saia daiteke deskripzio horiek aldatzen —ez pentsatu gizon baten lorpen famatuetan, baizik eta, demagun, beste zerbaitetan, eta saiatu hori gure deskripzio gisara erabiltzen-. Agian, nahikoa buelta eman eta gero, aterako du norbaitek zerbait hemendik; ${ }^{38}$ edonola ere, eskura dauzkagun saiakera gehienak kontradibideei edo bestelako objekzioei irekiak daude. Eman dezadan horren adibide bat. Gödelen kasuan, batek esan lezake 'Tira, "Gödel"ek ez du esan nahi "aritmetikaren osotasunik eza frogatu zuen gizona"". Begira, benetan dakigun gauza bakarra da jende gehienak uste duela Gödelek aritmetikaren osotasunik eza frogatu zuela, Gödel dela aritmetikaren osotasunik eza egotzi ohi zaion gizona. Beraz, 'Gödel' izenaren erreferentea mugatzen dudanean, ez diot nire buruari esaten "Gödel"en bitartez "aritmetikaren osotasunik eza frogatu zuen gizona, hori edozein izanda ere" esan nahi dut'. Hori Schmidt edo Post izatea suerta liteke. Horren ordez, zera esan nahi dut: 'jende gehienak aritmetikaren osotasunik eza frogatu zuela uste duen gizona'.

Zuzena al da hori? Aurrena, iruditzen zait lehenago eman ditudan kontradibideen antzekoak eman dakizkiokeela, nahiz eta kontradibide horiek bihurriagoak izango diren. Demagun, lehenago aipatutako Peanoren kasuan, hiztunak hala jakin gabe, jende gehiena (oraingoz behintzat) konturatzen dela zenbakien teoriaren axiomak ez litzaizkiokeela hari egotzi behar. Jende gehienak ez du Peano jotzen axiomen autoretzat, Dedekind baizik, zuzen. Beraz, kasu horretan ere gauza hori normalean egozten zaion gizona Dede-

37 Iradoki izan zait defenda litekeela izen bat deskripzio baten erabilera 'erreferentzial' batekin dagoela lotuta, Donnellanen zentzuan. Adibidez, Gödel osotasunik ezaren teoremaren autoretzat identifikatzen badugu ere, berari buruz ari gara hizketan baita gertatzen bada ere ez duela berak frogatu teorema. (2)-(6) tesiek huts egin lezakete, beraz; baina, edonola ere, izen bakoitzak deskripzio bat laburtuko luke, nahiz eta deskripzioak izendatzean jokatzen duen papera erradikalki desberdina izango litzatekeen Fregek eta Russellek imajinatu zuten haren aldean. Goian esan dudan moduan, Donnellanek deskripzio definitu erreferentzialen nozioaz ematen duen formulazioa ukatzera jotzen dut. Nolanahi ere, Donnellanen analisia onartzen bada ere, argi dago esku artean daukagun proposamen hau, berriz, ez litzatekeela onartu behar. Izan ere, deskripzio definitu erreferentzial bat, 'xanpaina edaten ari den gizona', adibidez, alde batera uzten baita hiztuna konturatzen denean ez zaiola bere objektuari egokitzen. Iruzur gödeliar bat argitara emango balitz, Gödeli ez genioke gehiago 'osotasunik ezaren teoremaren autorea' esango, baina jarraituko genuke hari 'Gödel' esaten. Izenak, beraz, ez du deskripzioa laburtzen.

38 Robert Nozickek ohartarazi zidan moduan, zentzuren batean deskripzio-teoria batek tribialki egiazkoa izan beharko du, izenen erreferentziaren teoriaren bat eman badaiteke, erreferentzia nozioaz independenteak diren terminotan emanda. Izan ere, halako teoria batek objektu bat izen baten erreferentea izateko baldintzak ematen baditu, orduan, noski, asetzen ditu baldintza horiek. Ez denez nire asmoa erreferentziaren nozioa zentzu horretan kentzen duen teoria bat ematea, ez dut ezagutzen deskripzio-teoria horrela tribialki betetzeko modurik, eta zalantzak dauzkat halakorik existituko ote den. (Izen baten erreferentziaren nozioa erabiliko duen deskripzio bat erraz osa daiteke, baina zirkularra da, Knealeri buruzko eztabaidan ikusi genuen moduan.) Deskripzio-teoria horrela tribialki bete ahalko balitz, edonola ere, eman ditudan argudioek erakusten dute deskripzioak guztiz desberdina izan beharko duela Fregek, Russellek, Searlek, Strawsonek eta deskripzio-teoriaren alde egin duten besteek gogoan zutenaren aldean. 
kind izango da, eta ez Peano. Nolanahi ere, hiztunak, jada ohikoa ez den uste zaharra mantenduta ere, Peanori egin diezaioke erreferentzia, eta uste faltsu bat mantenduko du Peanori buruz, eta ez egiazko uste bat Dedekindi buruz.

Baina, bigarrenik, eta, ziur asko esanguratsuagoa dena, halako irizpideak zirkularitaterik ezaren baldintza urratzen du. Nolatan? Egia da gutako gehienok uste dugula Gödelek frogatu zuela aritmetikaren osotasunik eza. Zergatik? Benetan diogu, eta zintzoki, 'Gödelek aritmetikaren osotasunik eza frogatu zuen'. Ondorioztatzen al da hortik uste dugula Gödelek aritmetikaren osotasunik eza frogatu zuela - aritmetikaren osotasunik eza gizon honi egozten diogula-? Ez. Hortik bakarrik ez. Gödeli erreferentzia egiten aritu behar dugu esaten dugunean 'Gödelek aritmetikaren osotasunik eza frogatu zuen'. Benetan beti Schmidti ariko bagina erreferentzia egiten, orduan aritmetikaren osotasunik eza Schmidti egozten ariko ginateke, eta ez Gödeli - 'Gödel' soinua 'Schmidt' esaten ari natzaion gizonaren izentzat erabiliko bagenu-.

Baina Gödeli egiten diogu erreferentzia, benetan. Nola egiten dugu hori? Tira, ez geure buruari esanez "Gödel"en bitartez esan nahiko dut aritmetikaren osotasunik eza egotzi ohi zaion gizona'. Hala egingo bagenu, zirkulu batean eroriko ginateke. Hemen gaude gu denok, gela honetan. Instituzio honetan ${ }^{39}$ batzuek gizonarekin topo ere egin dute, baina instituzio askotan hori ez da horrela. Komunitatearen kide garen guztiok erreferentzia mugatu nahian gabiltza, esanez 'Gödel izango da aritmetikaren osotasunik eza egotzi ohi zaion gizona'. Gutako inork ez dio ezer egotziko ez badago irizpide independenteren bat izenaren erreferentziarentzat 'aritmetikaren osotasunik eza egotzi ohi zaion gizona' horretaz aparte. Bestela, esaten ariko garen guztia izango da 'Lorpen hau egozten diogu egozten diogun gizonari', gizon hori nor den esan gabe, erreferentziaren irizpide independenterik eman gabe; eta, horrela, mugapena zirkularra izango da. Hori, beraz, ' $\mathrm{C}$ ' deitu dudan baldintza urratzea da, eta ezin da inongo erreferentziaren teoriatan erabili.

Noski, saia zaitezke zirkularitatea ekiditen, fardela pasatuz. Strawsonek aipatzen du hori: auzi hauei buruzko oin-ohar batean esaten du norbaiten erreferentzia erator daitekeela beste norbaitenetik.

Deskripzio identifikatzailearen parte ezin da izan hiztunak delako partikular jakinari egindako erreferentziari egindako erreferentzia bat; baina izan daiteke horren parte beste hiztun batek partikularrari egindako erreferentziari egindako erreferentzia bat. Deskripzio ustez identifikatzaile bat azken mota horretakoa bada, orduan, ea benetako deskripzio

39 Princeton Unibertsitatea. 
identifikatzailea delako auzia beste auzi hau bihurtzen da, erreferitzen duen erreferentzia benetako erreferentzia identifikatzailea ote den. Beraz, erreferentzia batek benetako erreferentzia identifikatzailea delako bermea maileguan har dezake beste erreferentzia batetik, eta hark beste batetik. Baina itzulera hau ezin da infinitua izan. ${ }^{40}$

Orduan, esan dezaket 'Begira, "Gödel"ekin esan nahiko dut Joeren ustez aritmetikaren osotasunik eza frogatu zuen gizona'. Joek, ostera, pasa diezaioke fardela Harryri. Kontu handia eduki behar da hau ez dadin zirkulu bihurtu. Guztiz ziur gaude ez dela horrelakorik gertatuko? Zu zeu ziur izan bazaitezke halako katea ezagutzen duzula, eta katean parte hartzen duten gainerako guztiak dagokion baldintzak betetzen ari direla eta, beraz, ez direla eurak katetik ateratzen, orduan, agian, irits zaitezke gizon harengana halako kate bati modu horretan erreferentzia eginez, erreferentziak banaka-banaka maileguan hartuz. Edonola ere, nahiz eta, oro har, horrelako kateak bai existitzen diren bizi direnentzat, ez duzu jakingo katea zein den. Ez zara ziur izango ze deskripzio ari den erabiltzen bestea, gauza ez dadin zirkulu batean erori, edo Joerengana joz ez ote zaren dagokion gizonarenganaino iritsiko. Beraz, ezin da hau ziurtasunez erabili deskripzio identifikatzaile moduan. Agian ez duzu gogoratu ere egingo noren bidez izan zenuen Gödelen berri.

Zein da gertatzen denaren irudi zuzena? Agian, erreferentzia ez da benetan gertatzen den zerbait ere! Azken finean, benetan ez dakigu gizona identifikatzeko erabiltzen ditugun propietateetatik bat bera ere zuzena ote den. Ez dakigu objektu bat eta bakarra hautatzen ote duten. Orduan, zer da 'Zizeron'en nire erabilera haren izen egiten duen hori? Deskripzio sortaren teoriara garamatzan irudia honako honen gisako zerbait da: isolatuta zaude gela batean; gainerako hiztunen komunitate osoa, gainerako guztia, desagertu ahal zen; eta zeure buruarentzat erreferentzia mugatzen duzu, esanez "Gödel"en bitartez esan nahiko dut aritmetikaren osotasunik eza frogatu zuen gizona, hori edonor izanik ere'. Tira, egin dezakezu hori, hala nahi baduzu. Ez dago benetan hori eragotziko dizun ezer. Euts diezaiokezu erabaki horri. Hori bada egiten duzuna, orduan, Schmidtek aurkitu bazuen aritmetikaren osotasunik eza, orduan bai egiten diozu erreferentzia berari esaten duzunean 'Gödelek halakoak eta halakoak egin zituen'.

Baina hori ez da gutako gehienok egiten duguna. Norbait jaiotzen da, haur bat adibidez; bere gurasoek izen bat ematen diote. Berari buruz hitz egiten diete euren lagunei. Beste batzuek ezagutu egiten dute. Hizketa modu ugariren bitartez izena zabaldu egiten da, katebegiz katebegi, katea balitz bezala. Kate horren muturrean dagoen hiztun batek, adibidez, Richard Feynmani buruz hizketan entzun duenak, merkatuan edo beste edozein lekutan, egin diezaioke erreferentzia Richard Feynmani, baita ez badu gogoan ere nor

40 Strawson: Individuals, 182. or., oin-oharra. 
entzun zuen lehenengoz Feynmani buruz hizketan edota nor entzun duen inoiz Feynmani buruz hizketan. Badaki Feynman fisikari ezaguna dela. Badago azkenean gizon harenganaino heltzen den komunikazio-pasabide bat, hiztunarenganaino ere heltzen dena. Feynmani erreferentzia egiten dio, beraz, nahiz eta ez den gai hura gainontzeko gauzengandik bereiziz identifikatzeko. Ez daki zer den Feynman diagrama bat, ez daki zer den bikoteen sorrera eta deuseztapenaren Feynman teoria. Ez hori bakarrik: arazoak izango lituzke Gell-Mann eta Feynman bereizten. Ez ditu zertan gauza horiek jakin, baina, halere, Feynmanengana berarengana iristen den komunikazio-kate bat ezarri da, katebegiz katebegi izena pasa duen komunitate baten kide izatearen bitartez, ez bere gelan pribatuan egiten duen zeremonia baten bitartez: "Feynman" ekin esan nahiko dut halakoak eta halakoak eta halakoak eta halakoak egin zituen gizona'.

Zertan desberdintzen da ikuskera hau lehenago aipatutako Strawsonen iradokizunetik, esaten duena erreferentzia identifikatzaile batek bere bermea beste batengandik maileguan har dezakeela? Jakina, aipatu dudan pasartean Strawsonek asmatzen du zuzena den zerbait harrapatzen; bestalde, hark dioena ziur desberdintzen da nik proposatzen dudan iruditik gutxienez enfasian, hark azalpena oin-ohar batera mugatzen baitu. Testu nagusiak deskripzio sortaren teoriaren alde egiten du. Strawsonek bere oharra deskripzio-teoria baten testuinguruan egiten duelako bakarrik, jada bere ikuskera nirearengandik desberdina da alderdi garrantzitsu bati dagokionez. Antza, Strawsonek eskatzen du hiztunak jakin behar duela norengandik jaso zuen bere erreferentzia, eta honela esan ahalko duela: "Gödel" ekin esan nahiko dut Jonesek "Gödel" esaten dion gizona'. Ez badu gogoratzen nola jaso zuen erreferentzia, ezin du halako deskripziorik eman. Esku artean daukagun teoriak ez du horrelako eskakizunik egiten. Esan dudan moduan, agian ez dut gogoratzen nor entzun dudan Gödeli buruz hizketan, edo uste izan dezaket gogoratzen dudala nori entzun nion izena eta oker egon.

Gogoeta horiek erakusten dute hemen proposatutako ikuskerak eraman gaitzakeela Strawsonen oin-oharrarenez bestelakoak diren ondorioetara. Demagun hiztunak 'Zizeron' izena Smithi eta bestetzuei entzun diela, eta haiek izen hori hizlari erromatar ezagun bati erreferentzia egiteko erabiltzen dutela. Geroago uste du, nolanahi ere, izena Jonesengandik jaso zuela, eta hark (hiztunak hala jakin gabe) 'Zizeron' espioi alemaniar garrantzitsu baten izentzat erabiltzen du, eta ez du inoiz ezer entzun Antzinaroko inongo hizlariri buruz. Orduan, Strawsonen ereduaren arabera, hiztunak bere erreferentzia mugatu behar du, honako erabaki honen bitartez: "Zizeron" erabiliko dut Jonesek izen horrekin esaten dion gizonari erreferentzia egiteko'; esku artean daukagun ikuskeraren arabera, berriz, erreferentea hizlaria izango da, nahiz eta hiztunak uste okerrak izan izena jasotzeko moduari buruz. Gauza da, komunikazio-katearen ikuskera deskripzio-teoria batean txertatu nahirik, Strawsonek sostengu gisa erabiltzen duela zein uste duen hiztunak dela bere errefe- 
rentziaren jatorria. Hiztunak jatorri hori ahaztu badu, Strawsonek erabiltzen duen deskripzio hori ez dago bere eskura; oker gogoratzen badu, Strawsonen ereduak emaitza okerrak eman ditzake. Gure ikuskeran, errelebantea dena ez da nola uste duen hiztunak jaso zuela erreferentzia, baizik eta benetan gertatzen den komunikazio-katea.

Uste dut aurrekoan esan nuela filosofia-teoriek faltsu izateko arriskua dutela, eta horregatik ez nuela teoria alternatibo bat aurkeztuko. Ez al dut horixe egin oraintxe? Tira, puntu bateraino; baina nire ezaugarritzea ez da izan erreferentziarako baldintza beharrezko eta nahikoen benetako multzo bat izango litzatekeena bezain zehatza —ezta gutxiago ere-. Bistakoa denez, izena katebegiz katebegi pasatzen da. Baina, noski, nigandik gizon jakin batengana doan kate kausal mota oro ez da egokia izango nik erreferentzia bat egin ahal izateko. Agian badago kate kausal bat 'Santa Claus' terminoaren gure erabileratik santu historiko partikular batenganaino; baina, halere, umeek, izen hori erabiltzen dutenean, egundo ez diote, seguru asko, santu horri erreferentzia egiten. Beraz, beste baldintza batzuk ase beharko dira hau benetan erreferentziaren teoria zehatza bihur dadin. Ez dakit hori egingo dudan; izan ere, hasteko, ez daukat horretarako gogo handirik oraintxe; bigarrenik, erreferentziaren moduko termino batentzat balioko duten baldintza beharrezko eta nahikoen multzo bat eman baino, jasotako ikuskerek ematen digutena baino irudi hobea aurkeztu nahi dut.

Ez al dut, akaso, pixka bat bidegabe jokatu deskripzio-teoriarekin? Hemen zehatz-mehatz aurkeztu dut — defendatzen duen edonork aurkeztu duena baino zehaztasun handiagoz, akaso- . Horrela erraza da gezurtatzea. Agian nire ikuskera zehaztasun nahikoz aurkezten saiatuko banintz, sei edo zazpi edo zortzi tesi emanez, gertatuko litzateke, tesiak banan-banan aztertuko bagenitu, den-denak faltsu suertatuko liratekeela. Agian horrela da, baina honako hau da desberdintasuna. Nire ustez, eman ditudan adibideek erakusten dutena ez da bakarrik halako arazo teknikoren bat dagoela hemen edo akatsen bat hor, baizik eta teoria honek erreferentziaren mugapenari buruz ematen duen irudi osoak okerra dirudiela oinarri-oinarrietatik. Okerra dirudi pentsatzeak geure buruari propietate batzuk ematen dizkiogula, nolabait objektu bakar bat kualitatiboki hautatzen dutenak eta gure erreferentzia modu horretan mugatzen dutenak. Aurkezten saiatzen ari naizena irudi hobe bat da -xehetasun gehiago emanez gero, erreferentzia gertatu ahal izateko baldintza zehatzagoak emateko nahikoa fina litzatekeen irudia-.

Baliteke baldintza beharrezko eta nahikoen multzo bat inoiz ez lortzea. Ez dakit, beti gustatu izan zait Butler apezpikuaren 'Gauza oro da den hori eta ez beste ezer' delakoa —zentzu ez-tribial batean; alegia, esanez erreferentziaren gisako kontzeptuak erreferentzia bera aipatzen ez duten termino guztiz desberdinetan ematen dituzten analisi filosofikoek oso erraz huts egingo dutela- . Noski, analisi bat ematen zaigun edozein kasu partikularretan, be- 
giratu egin behar diogu, eta egia ala faltsua den ikusi. Ezin dugu maxima hori aipatu eta, besterik gabe, orria pasatu. Baina, tentu handiagoz, irudi hobe bat aurkeztu nahi dut erreferentziarako baldintza beharrezko eta nahikoen multzorik eman gabe. Halako baldintzak oso konplexuak izango lirateke, baina egia dena da gizon partikular bati erreferentzia egiten diogula komunitateko beste hiztunekin daukagun lotura baten bidez, atzera erreferentearenganaino berarenganaino doana.

Egon daitezke kasu batzuk non deskripzioaren irudia egiazkoa den: non gizon batek benetan izen bat ematen duen, bere gelako pribatutasunera joz eta esanez erreferentea izango dela propietate identifikatzaile jakin batzuk dauzkan gauza bakarra. 'Jack tripa-urratzailea' zen eman nuen adibide posible bat. Beste bat 'Hesperus' zen. Deskripzio horretara behartu daitekeen beste adibide bat da norbait ezagutu eta bere izena esaten dizutenekoa. Ez bada deskripzio-teorian sinesten delako, bestelako kasuetan daukan garrantzian sinesten delako, seguru asko ez genuke pentsatuko hori dela norbere buruari deskripzio bat ematen zaion kasu bat; alegia, 'oraintxe bertan ezagutzen ari naizen tipoa'. Baina jar daiteke termino horietan, hala nahi bada, eta ez bada izena beste edozein modutan entzun. Noski, gizon bat aurkeztu eta esaten badizute 'Hori Einstein da', baduzu bere berri lehenagotik, oker egon daiteke, eta horrela. Baina, agian, kasu batzuetan halako eredu batek funtzionatzen du - bereziki, norbaiti edo zerbaiti izena lehenengo aldiz ematen dion gizonarentzat-. Edo, norbaitek izar bat atzamarraz seinalatu, eta zera dio: 'Hori izango da Alpha Centauri'. Benetan egin dezake honako zeremonia hau: "Alpha Centauri"ren bitartez esan nahiko dut hortxe dagoen izarra, halako eta halako koordenatuetan'. Baina, oro har, irudi honek huts egiten du. Oro har, gure erreferentzia ez da soilik guk geuk pentsatzen dugun horren araberakoa, baizik eta komunitatean dauden beste pertsonen araberakoa, izenak gureganaino egin duen bidearen eta horrelako gauzen araberakoa. Horrelako bideari jarraituz heltzen gara erreferentziaraino.

Baldintza zehatzagoak ematea oso konplexua da. Moduren batean nolabait desberdinak dirudite gizon famatu baten kasuan eta hain famatua ez den baten kasuan. Adibidez, irakasle batek esaten die bere ikasleei Newton famatua zela lehenengo gizona izan zelako pentsatzen badagoela indar bat gauzak lurrera erakartzen dituena; uste dut hori dela umeek Newtonen lorpen handientzat jotzen dutena. Ez dut esango ze meritu izango lukeen horrelako lorpen batek, baina, edonola ere, pentsa dezakegu Newtonen aurkikuntzaren eduki bakarra hori dela esateak uste faltsu bat ematen diela ikasleei Newtoni buruz, nahiz eta ez duten lehenagotik haren berri. Bestalde, ${ }^{41}$ irakasleak 'George Smith' izena erabiltzen badu — horrela izena duen gizon bat bizilagun du atez ate-, eta esaten badu George Smith izan zela zirkulua

41 Adibide honen puntu esentzialak Richard Millerrek iradoki zizkidan. 
laukitzen lehena, hortik ondorioztatzen al da ikasleek uste faltsu bat daukatela irakaslearen bizilagunari buruz? Irakasleak ez die esaten Smith bere bizilaguna dela; ez du, ezta ere, uste Smith izan zela zirkulua laukitzen lehena. Ez da zehazki saiatzen ari bizilagunari buruzko inolako usterik ikasleen buruan sortzen. Zirkulua laukitu zuen gizona badagoelako ustea sorrarazi nahian ari da, eta ez gizon zehatz bati buruzko usterik — burura datorkion lehen izena hartu besterik ez du egin-, eta bere bizilagunaren izena erabili du. Ez dago argi kasu horretan ikasleek bizilagunari buruzko uste faltsu bat daukatela, nahiz eta badagoen kate kausal bat atzera bizilagunarengana iristen dena. Ez nago ziur honi buruz. Edonola ere, zehaztapen eta ñabardura gehiago gehitu beharra dago hau baldintza beharrezko eta nahikoen multzoa izaten has dadin ere. Zentzu horretan, ez da teoria bat, baina benetan gertatzen denaren irudi hobea ematea espero da.

Honako hau izan daiteke teoria baten lehen bertsio bat. Lehen 'bataio' bat egiten da. Hemen objektua ostentsio bidez izenda daiteke, edo izenaren erreferentzia deskripzio bidez zehaztu daiteke. ${ }^{42}$ Izena 'katebegiz katebegi pasatzen' denean, izena jasotzen duenak izan behar du, nire ustez, ikasten duenean izena entzun zion pertsonak ematen zion erreferentzia berberarekin erabiltzeko asmoa. 'Napoleon' izena entzuten badut eta erabaki izen polita izango litzatekeela maskotatzat dudan akuritxoarentzat, ez dut baldintza hori asetzen. ${ }^{43}$ (Agian, gisa horretako erreferentzia mantentzeko hutsegiteak dira 'Santa Claus' izenaren egungo erabileraren eta ustezko jatorrizko erabileraren arteko desadostasuna azaltzen dutenak).

Ohartarazi nahi dut aurreko eskema horrek ez duela erreferentziaren nozioa kentzen; alderantziz, emantzat jotzen du erreferentzia berarekin erabiltzeko asmoaren nozioa. Hasierako bataio bat ere aipatzen da, eta hori erre-

42 Bere erreferentzia deskripzio baten bitartez zehaztu zen bataio baten adibide ona Neptunoren izen-ematea da, 33. oin-oharrean. Agian, deskripzio-kontzeptuak bil dezake, baita ere, ostentsio bidez egiten den bataioaren kasua. Honela, deskripzio-teoriaren aplikazio nagusia lehen bataio kasuei dagokie. Deskripzioak erreferentzia zehazteko erabiltzen dira, halaber, designazio kasu batzuetan, izendatzeen antzekoetan, baina alde batekin: sartzen diren terminoei ez zaiela normalean 'izen' esaten. 'Metro bat' eta '100 gradu zentigradu' eman dira jada adibide gisa, eta beste adibide batzuk emango dira geroago hitzaldi hauetan. Bi gauza azpimarratu beharko lirateke lehen bataio batean izen bat deskripzio baten bitartez sartzen den kasuaren inguruan. Bat, erabiltzen den deskripzioa ez da sartzen den izenaren sinonimoa; hori baino, bere erreferentzia zehazten du. Horretan ez gaude ados deskripzio-teoriaren ohiko defendatzaileekin. Bi, lehen bataio kasu gehienak urrun daude hasiera batean deskripzio-teoria inspiratu zutenetatik. Normalean bataioa egiten duenak kontaktu zuzena dauka, zentzuren batean, izendatzen duen objektuarekin, eta gai da hori ostentsiboki izendatzeko. deskripzio-teoria inspiratzen duena da sarri erabil ditzakegula aspaldi hil ziren pertsonaia famatuen izenak, bizi den inork haiekin kontaktu zuzenik izan gabe; eta, hain justu, kasu horiek dira, gure iritziz, deskripzio-teoria batekin egoki azaldu ezin direnak.

43 Pasa diezaieket akuritxoaren izena beste pertsonei. Pertsona horietako bakoitzarentzat, niretzat bezala, egongo da lotura kausal edo historiko bat izenaren nire erabileraren eta frantziarren Enperadorearen artean, baina ez behar den modukoa. 
ferentzia deskripzio bidez zehaztearen terminoetan edo ostentsio bidez zehaztearen terminoetan azaltzen da (ostentsioa ez badu beste kategoriak bildu behar). ${ }^{44}$ (Agian badaude beste aukera batzuk hasierako bataioentzat.) Gainera, George Smithen kasuak zalantzak sortzen ditu baldintzen nahikotasunari buruz. Irakasleak bere bizilagunari erreferentzia egiten baldin badio ere, argi al dago bere erreferentzia ikasleei pasatu diela? Zergatik ez da izango horien ustea 'George Smith' izena duen beste edozein gizoni buruzkoa? Newtonek sagar baten kolpea jaso zuela esaten badu, nolabait erreferentzia transmititzearen bere lana errazagoa da, Newtoni buruz ohikoa den uste oker bat komunikatu baitu.

Berriro esatearren, agian ez dut teoria bat aurkeztu, baina bai uste dut deskripzio-teoriaren defendatzaileek eskaintzen dutena baino irudi hobea aurkeztu dudala.

Uste dut landu nahi dudan hurrengo gaia identitate-baiezpenena dela. Beharrezkoak ala kontingenteak dira? Dezente eztabaidatu da auziari buruz azken urteotan filosofian. Aurrena, denok gaude ados deskripzioak erabil daitezkeela identitate-baiezpen kontingenteak egiteko. Egia bada bifokalak asmatu zituen gizona zela Ameriketako Estatu Batuetako Posta Zerbitzuko lehenengo zuzendaria — horiek bat eta bera zirela-, kontingenteki da egia. Hau da, gerta izan zitekeen gizon batek asmatu izana bifokalak, eta beste bat izatea Ameriketako Estatu Batuetako Posta Zerbitzuko lehenengo zuzendaria. Beraz, ziur, identitate-baiezpenak egiten direnean deskripzioak erabiliz — esaten denean ' $\phi x$ den $x$ eta $\psi x$ den $x$ bat eta berbera dira' $-{ }^{*}$ hori izan daiteke gertakari kontingente bat. Baina filosofoak interesatu dira izenen arteko identitate-baiezpenen auziaz ere. Esaten dugunean 'Hesperus Phospho-

44 Behin ohartzen garenean izen baten erreferentzia zehazteko erabili den deskripzioa ez dela haren sinonimoa, uler daiteke deskripzio-teoriak izendatzearen edo erreferentziaren nozioa aurresuposatzen duela. Lehenago egin dudan eskakizuna, esaten duena erabiltzen den deskripzioak berak ez duela erreferentziaren nozioa modu zirkularrean erabili behar, beste zerbait da, eta ezinbestekoa da, deskripzio-teoriari inolako baliorik emango badiogu. Horren arrazoia da deskripzioteoriaren defendatzaileak emantzat jotzen duela hiztun bakoitzak hasiera bateko izendatzeekintza batean ematen duen deskripzioa erabiltzen duela bere erreferentzia mugatzeko. Bistan denez, 'Zizeron' izena sartzen badu honako mugapen honekin, "'Zizeron” izenarekin erreferentzia egingo diot "Zizeron" esaten diodan gizonari', zeremonia horren bitartez ez du inolako erreferentziarik mugatu.

Ez zuten deskripzio-teoriaren defendatzaile guztiek pentsatu horrela erreferentziaren nozioa erabat kentzen ari zirenik. Agian, batzuk konturatu ziren ostentsio nozioren bat, edo erreferentzia primitibo nozioren bat, bai behar dela sostengu moduan. Ziur naiz Russell konturatu zela.

* 'the $x$ such that $\phi x$, and the $x$ such that $\psi x$ are one and the same', jatorrizkoan. Hemen, Kripke deskripzio definituei buruz ari da; alegia, ingelesez 'the' artikuluarekin hasten diren adierazpenei buruz. Euskaraz horiek $-a$ atzizkiarekin egin ohi dira, nahiz eta $-a$ atzizki hori seguru asko ez den ingelesezko 'the' artikuluaren itzulpen zehatza; hemen, gainera, euskarazko bertsioan $x$ ri - $a$ atzizkia jarriz ez da begi-bistakoa Kripke deskripzio definituei buruz ari dela (eta hala ari da) -itzultzailearen oharra-. 
rus da' edo 'Zizeron Tulio da', esaten ari garena beharrezkoa da ala kontingentea? Are gehiago, batzuk interesatu dira beste identitate-baiezpen mota batean, teoria zientifikotik datorrena. Identifikatzen dugu, adibidez, argia uhin-luzera limite batzuen arteko erradiazio elektromagnetikoarekin, edo fotoi sorta batekin. Beroa molekula-mugimenduarekin identifikatzen dugu; soinua, airean gertatzen diren mota jakin bateko uhin-perturbazioekin; eta horrela. Horrelako baiezpenei dagokienez, ohikoa da honako tesi honi eustea. Aurrena, begi-bistakoa dela horiek identitate kontingenteak direla: argia fotoi sorta dela aurkitu dugu, baina, noski, bazitekeen fotoi sorta bat ez izatea. Beroa molekula-mugimendua da, izatez; aurkitu genuen hori, baina bazitekeen beroa ez izatea molekula-mugimendua. Bigarrenik, filosofo ugari benetan zorteko sentitzen da halako adibideak eskura izateaz. Zergatik, bada? Filosofo horiek, eta euren ikuskerek literatura zabala daukate, 'identitate-tesia' deritzon tesia onartzen dute kontzeptu psikologiko batzuei dagokienez. Pentsatzen dute, adibidez, mina garunaren edo gorputzaren egoera jakin bat dela, edo horrelako zerbait —demagun, C-zuntzen estimulazioa, adibidez (ez dio inporta zer)—, eta ez besterik. Batzuek honela egin diete kontra: 'Tira, begira, badago agian korrelazio bat minaren eta gorputzaren egoera horien artean; baina horrek izan behar du besterik gabe bi gauza desberdinen arteko korrelazio kontingente bat, aurkikuntza enpirikoa izan baitzen korrelazio hori betetzen dela. Horregatik, "mina" ren bitartez esan nahi duguna desberdina da, derrigorrez, gorputzaren edo garunaren egoera horretatik; eta, horregatik, bi gauza desberdin izan beharra daukate.'

Eta, gero, esaten dute 'Ah, baina, begira, hori okerra da! Mundu guztiak daki egon daitezkeela identitate kontingenteak'. Aurrena, bifokalen eta Posta Zerbitzuko zuzendariaren kasua bezalakoetan, lehenago aipatu dudana. Bigarrena, identifikazio teorikoen kasuan, ustez esku artean daukagunari gertukoago zaiona, argia eta fotoi sortarena, adibidez, edota ura eta hidrogeno eta oxigeno konposatu batena. Horiek identitate kontingenteak dira, denak. Bazitekeen horiek faltsu izatea. Ez da harritzekoa, beraz, gertakari kontingenteen oinarrian izan daitekeela egia, eta ez beharrezkoak diren gertakariengatik, mina sentitzea edo gorri ikustea giza gorputzaren egoerak izatea, eta ez beste ezer. Halako identifikazio psikofisikoak gertakari kontingenteak izan daitezke, gainerako identitateak gertakari kontingenteak diren modu berean. Eta, noski, badaude jendea tesi horretan sinetsi nahi izatera daramaten motibazio aski zabalduak —ideologikoak, edo, besterik gabe, onartu nahi ez izatea fisikaren legeek azaltzen ez dituzten lotura misteriotsuko 'irekigune nomologiko' bat, banakako korrelazioak klase desberdineko gauzen artean, egoera material eta klase guztiz desberdineko gauzen artean-.

Uste dut landuko dudan aurreneko gai nagusia izenen arteko identitatebaiezpenena izango dela. Baina honako hau defendatzen dut kasu orokorrari buruz. Aurrena, 'Beroa molekula-mugimendua da' gisako ohiko identifikazio teorikoak ez direla egia kontingenteak, beharrezko egiak baizik; eta hemen, 
noski, ez dut esan nahi fisikoki beharrezkoa bakarrik, baizik eta beharrezkoa maila altuenean - horrek esan nahi duena edozer izanik ere-. (Suerta liteke beharrezkotasun fisikoa izatea maila altueneko beharrezkotasuna. Baina hori aurrez epaitu nahi ez dudan auzia da. Mota honetako adibideen kasuan, behintzat, izan daiteke zerbait fisikoki beharrezkoa denean beti dela beharrezkoa tout court.) Bigarrena, horiek beharrezko egia suertatu diren modua ez zaidala iruditzen niri gogo-garun identitateek egia beharrezko edo kontingente suertatzeko izan dezaketen modu bat. Beraz, analogia hori alde batera utzi behar dugu. Zaila da ikusten zer jar dezakegun horren ordez. Zaila da ikusten, horregatik, nola saihestu daitekeen ondorioztatzea biak benetan desberdinak direla.

Itzul nadin izen propioei buruzko auzi arruntagora. Hori jada bada nahikoa misteriotsua. Badago horri buruzko eztabaida Quineren eta Ruth Barcan Marcusen artean. ${ }^{45}$ Marcusek dio izenen arteko identitateak beharrezkoak direla. Norbaitek uste badu Zizeron Tulio dela, eta benetan erabiltzen baditu 'Zizeron' eta 'Tulio' izen gisa, derrigortuta dago orduan onartzera bere ustea beharrezkoa dela. Marcusek 'etiketa hutsa' terminoa darabil. Quinek honela erantzuten dio: 'Etiketa dezakegu Artizarra, ilunabarrean, "Hesperus" izen propioarekin. Etiketa dezakegu berriro planeta berbera, egunen bateko egunsentian, "Phosphorus" izen propioarekin. Planeta berbera birritan etiketatu dugula konturatzen garenean, gure aurkikuntza enpirikoa da. Eta ez izen propioak deskripzioak zirelako.'46 Aurrena, Quinek dioen moduan, planeta bera birritan etiketatu genuela konturatu ginenean, gure aurkikuntza enpirikoa izan zen. Uste dut Quinek ematen duela beste adibide bat beste libururen batean, mendi berari Nepaldik ikusita eta Tibetetik ikusita, edo horrelako zerbait, desberdin esaten zaiola: ikuspuntu batetik 'Everest' esaten zaio (hau entzun duzue lehenago), bestetik 'Gaurisanker' esaten omen zaio. Benetan aurkikuntza enpirikoa izan daiteke Gaurisanker Everest dela. (Quinek egiaz adibidea faltsua dela dio. Adibidea Erwin Schrödingerren eskutik jaso zuen. Nork pentsatuko zuen uhin-mekanikaren asmatzaileak ezer hain oker ulertuko zuenik. Ez dakit nondik ote datorren okerra. Ziur imajina daiteke egoera hau benetan gertatzen dela; eta Quinek buruan daukanaren beste adibide on bat da).

Eta horri buruz, zer? Bestelako jarrera daukan Marcusen aipu on bat aurkitu nahi nuen liburuan, baina zaila zait bat topatzea. Eztabaidan aurrean nengoenez, gogoan dut ${ }^{47}$ defendatzen zuela, benetan izenei buruz ari bagara, hiztegi on batek gai izan beharko lukeela ea erreferentzia berbera daukaten

45 Ruth Barcan Marcus: 'Modalities and Intensional Languages' (W. V. Quinen oharrak, gehi eztabaida) Boston Studies in the Philosophy of Science, I. bolumena, Reidel, Dordrecht, Holanda, 1963, 77-116.

46 101. or.

47 115. or. 
esateko. Beraz, batek gai izan beharko luke, hiztegian begiratuz, Hesperus eta Phosphorus gauza bera direla esateko. Baina ez dirudi hori horrela denik. Bai iruditzen zaio, jende askori, izenen arteko identitatea beharrezko izatearen ondorioa dela. Horregatik, izenen arteko identitate-baiezpenak beharrezko direlako ikuskera ukatu egin ohi da maiz. Russellen ondorioa zerbait desberdina zen. Pentsatzen zuen ez lukeela inoiz inolako auzi enpirikorik egon behar ea bi izenek erreferentzia berbera daukaten ala ez. Hori ohiko izenek ez dute betetzen, baina bai betetzen da zeure zentzumen-datu propioak izendatzen ari bazara, edo horrelako zerbait. Esaten duzu 'Horra, hori eta hura (bi erakusleekin zentzumen-datu bera designatuz)'. Eta, horrela, badakizu, ikerketa enpirikorik gabe, gauza bera birritan izendatzen ari zarela; baldintzak bai betetzen dira hor. Hori ez denez gertatuko izendatze-kasu ohikoetan, ohiko 'izenak' ezin dira izan benetako izenak.

Zer pentsatu beharko genuke horri buruz? Aurrena, egia da batek erabil dezakeela 'Zizeron' izena Zizeroni erreferentzia egiteko, eta 'Tulio' izena ere Zizeroni erreferentzia egiteko, eta ez jakin Zizeron Tulio dela. Beraz, badirudi ez dugula zertan a priori jakin izenen arteko identitate-baiezpen bat egiazkoa dela. Hortik ez da ondorioztatzen horrela adierazitako baiezpena kontingentea dela, egia bada. Hori da nire lehenengo hitzaldian azpimarratu dudana. Badago bihozkada indartsu bat pentsatzera eramaten gaituena, ezin bada zerbait a priori arrazoiketaren bidez ezagutu, orduan kontingentea izan behar duela: suerta izan zitekeen bestela; baina, edonola ere, bihozkada hori okerra dela uste dut.

Demagun birritan egiten diogula erreferentzia gorputz zerutar berberari, 'Hesperus' eta 'Phosphorus' gisara. Esaten dugu: Hesperus ilunabarrean hor inguruan dagoen izar hori da; Phosphorus goizaldean hor inguruan dagoen izar hori da. Egiaz, Hesperus Phosphorus da. Ba al daude benetan Hesperus Phosphorus izango ez zatekeen zirkunstantziak? Hesperus Phosphorus dela emantzat joz, saia gaitezen deskribatzen hala izango ez zatekeen egoera posible bat. Tira, erraza da. Badabil norbait hortik eta bi izar desberdini 'Hesperus' eta 'Phosphorus' esaten die. Guk 'Hesperus' eta 'Phosphorus' izenak sartu genituenean betetzen ziren baldintza berberetan ere gerta daiteke. Baina egia al da zirkunstantzia horietan Hesperus ez dela Phosphorus edo zirkunstantzia horietan Hesperus ez zatekeela Phosphorus izango? Ezetz iruditzen zait.

Orain, noski, nik esan beharra daukat ezetz, esateagatik 'Hesperus' eta 'Phosphorus' gisako terminoak, izen gisa erabiltzen direnean, designatzaile zurrunak direla. Mundu posible orotan Artizarra erreferitzen dute. Horregatik, mundu posible horretan ere, Artizarra Artizarra da eta ez dio inporta beste edozein pertsonak zer esan duen beste mundu posible horretan. Nola deskribatu beharko genuke guk egoera hori? Ezin izan du Artizarra birritan seinalatu, eta kasu batean hari 'Hesperus' esan eta bestean 'Phosphorus', guk egin dugun moduan. Hala egin izan balu, orduan 'Hesperus Phosphorus 
da' egiazkoa izango zatekeen egoera horretan ere. Agian ez zuen ez batean ez bestean Artizarra seinalatuko - gutxienez bietako batean ez zuen Artizarra seinalatuko; demagun, 'Phosphorus' esan zion gorputza seinalatu zuenean-. Orduan, kasu horretan esan dezakegu ziur bazitekeela 'Phosphorus' izenak Phosphorusi erreferentzia ez egitea. Guk goizaldean begiratutakoan Phosphorus aurkitu genuen posizioa hartu, eta bertan Phosphorus ez egotea gerta zitekeela ere esan dezakegu — beste zerbait zegoela hor eta, zirkunstantzia jakin batzuetan, 'Phosphorus' esan ere egingo ziotela-. Baina hori ez da oraindik Phosphorus Hesperus izango ez litzatekeen kasu bat. Baliteke egotea mundu posible bat, egoera kontrafaktiko posible bat, non 'Hesperus' eta 'Phosphorus' ez diren egiazki izendatzen dituzten gauzen izenak. Norbaitek, horien erreferentzia deskripzio identifikatzaileen bitartez mugatuko balu, erabil zitzakeen guk erabilitako deskripzio identifikatzaile berberak ere. Baina hori ez da oraindik Hesperus Phosphorus ez zatekeen kasu bat. Ezin baitzen halako kasurik izan, Hesperus Phosphorus baita.

Baina horrek oso arraroa dirudi; izan ere, badaukagu aldez aurretiko joera esateko bazitekeela Hesperus Phosphorus delako auziaren erantzuna bitako edozein modutan suertatzea. Ez al daude, beraz, benetan bi mundu posible - batean Hesperus Phosphorus litzateke, bestean Hesperus ez litzateke Phosphorus_-, guk horiek gauza bera direla aurkitu aurretik? Bat, egia da zentzu batean balitekeela gauzak edozein modutan suertatzea, baina argi dago zentzu horretan ez dela ondorioztatzen gauzek azkenean suertatzeko daukaten modua ez dela beharrezkoa. Adibidez, baliteke lau koloreen teorema egiazko suertatzea, eta baliteke faltsu suertatzea. Bitara suerta liteke. Ez du esan nahi suertatzen den modua ez dela beharrezkoa. Begi-bistakoa denez, 'baliteke' eta 'liteke' guztiz epistemikoak dira hor —uneko ezjakintasuna edo ziurtasunik eza adierazten du, besterik gabe-.

Baina badirudi Hesperus-Phosphorus kasuan zerbait are gogorragoa ere egia dela. Hesperus Phosphorus dela jakin aurretik daukadan ebidentzia da izar jakin bat edota gorputz zerutar jakin bat ikusten dudala ilunabarrean, eta 'Hesperus' esaten diodala; eta berdin goizean, eta 'Phosphorus' esaten diodala. Horiek badakizkit. Ziur, badago mundu posible bat non gizon batek izar jakin bat posizio jakin batean ikusiko lukeen ilunabarrean eta hari 'Hesperus' esango liokeen, eta izar jakin bat goizaldean eta horri 'Phosphorus' esango liokeen; eta ondorioztatu beharko lukeen —aurkitu beharko lukeen ikerketa enpirikoaren bitartez- bi izar desberdin izendatzen dituela, edo bi gorputz zerutar desberdin. Gutxienez bi izar edo gorputz zerutar horietako bat ez litzateke Phosphorus izango; bestela, ezin izango zatekeen modu horretan suertatu. Baina hori egia da. Eta, beraz, egia da ikerketa enpirikoa baino lehenago norbaitek daukan ebidentziaren oinarrian, egon daitekeela zentzuren batean zehazki egoera berean, hau da, kualitatiboki identikoa den egoera epistemiko batean, eta esan bi gorputz zerutarri 'Hesperus' eta 'Phosphorus', horiek identikoak izan gabe. Beraz, zentzu horretan bai 
esan dezakegu bazitekeela bitako edozein modutan suertatzea. Ez, ordea, bazitekeela bitako edozein modutan suertatzea Hesperus Phosphorus izateari dagokionez. Nahiz eta aldez aurretik genekien guztiagatik Hesperus ez zen Phosphorus, hori ezin zen beste edozein modutan suertatu, zentzu batean. Baina, kualitatiboki hitz eginda, zehazki ebidentzia berbera daukagun egoera batean jarrita, suertatu ahal zen Hesperus Phosphorus ez izatea; hau da, 'Hesperus' eta 'Phosphorus' guk erabiltzen ditugun moduan erabiltzen ez diren mundu kontrafaktiko batean, planeta honen izentzat ez baizik eta beste objekturen batzuen izentzat, batek izan ahal zuen ebidentzia kualitatiboki identikoa eta ondorioztatu 'Hesperus' eta 'Phosphorus' terminoek bi objektu desberdin izendatzen zituztela. ${ }^{48}$ Baina guk, izenak oraintxe bertan erabiltzen ditugun moduan erabiliz, esan dezakegu aldez aurretik, Hesperus eta Phosphorus gauza bat eta berbera badira, orduan ezin direla inongo mundu posibletan desberdinak izan. 'Hesperus' erabiltzen dugu gorputz jakin baten izen gisa; eta 'Phosphorus', gorputz jakin baten izen gisa. Gorputz horien izen gisa erabiltzen ditugu mundu posible guztietan. Gorputz bera badira, orduan beste edozein mundu posibletan objektu horren izen gisa erabili behar ditugu. Eta, orduan, beste edozein mundu posibletan egia izango da Hesperus Phosphorus dela. Beraz, bi gauza dira egia: bat, ez dakigula a priori Hesperus Phosphorus dela, eta ez gaudela erantzuna aurkitzeko moduan, ez bada enpirikoki. Bi, hori horrela da izan ahal genuelako daukagun ebidentziatik kualitatiboki bereizezina zitekeen ebidentzia eta bi izenen erreferentzia mugatu bi planetek zeruan daukaten posizioaren bitartez, planetak bat eta berbera izan gabe.

Noski, kontingenteki bakarrik da egia (ez egia mundu posible orotan) ilunabarrean hor zehar ikusten den izarra goizean hor zehar ikusten den izarra dela, bai baitaude mundu posibleak non Phosphorus ezin den ikusi goizean. Baina egia kontingente hori ez litzateke berdindu behar Hesperus Phosphorus delako baiezpenarekin. Hala berdindu ahalko litzateke bakarrik pentsatuko bagenu beharrezko egia dela Hesperus hor zehar ikus daitekeela ilunabarrean edota Phosphorus hor zehar ikus daitekeela goizaldean. Baina horietako bat bera ere ez da egia beharrezkoa, ezta planetak modu horretan hautatzen baditugu ere. Horiek planeta jakin bat identifikatzeko eta hari izena emateko erabiltzen ditugun zantzu kontingenteak dira.

48 Hirugarren hitzaldian puntu honen eztabaida garatuagoa dago, eta han aipatzen da, baita ere, kontraparteen teoria mota batekin daukan erlazioa. 